\title{
A TQM VEZETÉSI FILOZÓFIA ÉS A MINŐSÉGORIENTÁLT VEZETÉSI RENDSZEREK
}

\author{
(HAT SZIGMA, LEAN MANAGEMENT STB.)
}

A termeló- és szolgáltatószektorokban ma már természetes követelmény a minőségmenedzsment-rendszerek alkalmazása. A formalizált rendszerek mellett mind nagyobb szerepet kapnak a minôségorientált vezetési rendszerek. A szakmai közvéleményben is vita folyik arról, hogy e rendszereket különálló, egymástól független vagy azonos alapokon nyugvó rendszereknek tekintjük. Másrészt lényegét tekintve vezetési rendszereknek, filozófiáknak értelmezzük óket vagy különböző módszerek összességeként. A szerző cikkében a minőségmenedzsment-rendszerek jövőjével kapcsolatos trendek összefoglalása, a TQM, a Hat Szigma, valamint a lean management alapjainak áttekintése és összehasonlítása alapján megállapítja, hogy e rendszerek a vezetési rendszer szerves részét képezik, alkalmazásuk együtt jár az alkalmazó szervezet szervezeti kultúrájának megváltoztatásával. Az áttekintett vezetési rendszerek mindegyike a különbözó menedzsmentdiszciplínák szinergikus alkalmazását igényli. Hatékony múködésük feltételezi a különbözó módszerek szisztematikus alkalmazását, de pusztán a módszerek alkalmazása nem tekinthetố vezetési rendszernek.

Kulcsszavak: minôségmenedzsment, Total Quality Management (TQM), Hat Szigma, Six Sigma, lean management

Az utóbbi évtizedben mind gyakrabban felmerülő kérdés, hogy a minôségmenedzsment-rendszerek szerepe hogyan változik a szervezetek múködésében, vezetési rendszerében. A formalizált minôségmenedzsmentrendszerek (mint például az általánosan alkalmazható ISO 9000 szabványrendszernek megfelelố rendszerek, vagy pl. a szektorspecifikus GMP, QS 9000, HACCP) mellett jelentôs szerepet kapnak a minőségorientált vezetési rendszerek vagy vezetési filozófiák (pl. TQM, Hat Szigma, lean management).

A hazai minőségmenedzsment-élet egyik elismert szakembere, Rózsa András felteszi a kérdést: „Lean, Hat Szigma, avagy mi lesz veled TQM?" (Rózsa, 2009: 45.) Tényleg túl vagyunk a TQM vezetési filozófián? Az említett megközelítések valóban meróben más utakat jelentenek a szervezetek minóségorientált vezetésében, vagy valami másról van szó? Ezekre a kérdésekre keressük a választ cikkünkben. Tekintsük át az említett rendszerek alapjait, illetve vizsgáljuk meg a minőségmenedzsment-rendszerek szerepével, jövőjével kapcsolatos várható változásokat!

\section{A minôségmenedzsment-rendszerek jövôje}

Az utóbbi években több szerző is foglalkozik a minőségmenedzsment-rendszerek szerepének változásával és jövớbeli szerepével a minőségorientált szervezetek életében.

A szervezetek sikeres múködése, a kiválóság, mint kihívás, eléréséhez nem léteznek általánosan használható megoldások. Az új megoldások keresésében kiemelt szerepet kap az innováció és az integráció. A kiválósághoz az adott szervezetre szabott innovatív és egyedi megközelítéseket kell alkalmazni. Az EUban és az USA-ban is széleskörúen megjelenik a szervezeti szintú innováció szükségessége. Ez tekinthetố a nemzetközi minôségügyi mozgalom következô fókuszának. Az integráció a következő területeken kap jelentős szerepet:

- hatékony és hatásos minőségmenedzsment-elvek és -módszerek alkalmazása az üzleti folyamatokban, beleértve a stratégiai és operatív menedzsmentet is, 
- az üzleti folyamatok és teljesítmény folyamatos fejlesztése, amelynek nélkülözhetetlen eleme az állandó szervezeti tanulás,

- érdemi integráció a szervezet múködésében. A különböző vállalati alrendszerek (minôség, környezet, egészségbiztonság, információbiztonság) integrálása nem jelent üzleti értelemben vett integrációt.

A szervezetek jelenleg alkalmazott menedzsmentinfrastruktúrájába és üzleti környezetébe beágyazva, innovatív módon, az adott szervezetre jellemzó üzle hangsúlyokkal kell a minőségmenedzsment-szemlélete és annak eszköztárát alkalmazni (Anttila, 2008). Anttila következtetéseinek jelentős része a TQM vezetési filozófia által képviselt elveket erósíti, mint példán:

- „A korlátozott minóségértelmezés helyett az üzleti teljesítmény kiválóságának elismerése.

- „A különálló és meghatározatlan minóségmenedzsment helyett a menedzsment és a vezetés minôségé - "A

- a formális és kïlönálló minöségügyi rendserek

"helyett a menedzsment és a vezetés minüs egerek rendszerszerü megközelítése" (Anttila, 2008: 25.).

A minőségmenedzsment és a menedzsment minóÁnek kapesoluta egyméshoz való viszonya újaségének kapesolutá én ban elốt ge a tágabb entelenben vett erdekelt felek gyakra egymással ellentétes érdekeinek kielégítése alapjân ítélhetó meg. Kulcskérdés, hogy a közvetlen partneri igények és a fenntartható fejlő́dés összetevói (társdalmi, természeti, gazdasági és technikai), valamint társadalmi felelôsségvállalás egyes szempontjai közö a szervezet vezetése milyen összhangot tud teremten A menedzsment minőségének fejlesztésénél építhetün a minőségmenedzsment kipróbált módszereire is (Varga, 2008).

A minőségmenedzsment és a vállalati stratégia alakításában az utóbbi években jelentôs felfogásbel változás kezdődött meg. A TQM filozófí́ja szerint az vátoźs kezdón uzzleti eréc sek, ha a tevekenysegek nín és a munkatársak egyaránt a vevoôi megelégedettsé elérésén munkálkodnak. A szervezet minőségfejlesztési programjai csak akkor sikeresek, ha valamenny termelési tényezốt felölelik, szervesen illeszkednek minden tevékenységbe és gazdaságilag racionálisa (Parányi, 2006)

A minőség fogalmának komplex, tág értelmezését mutatja az Amerikai Minőségügyi Szervezet által öszszeállított tanulmány a minőség jövoóképét meghatá- rozó fontosabb tényezókról. A globalizáció hatása a vállalati múködésben új dimenziókat nyit meg, de a minőségmenedzsment-rendszereknek együtt kell kezelniük a globalizáció következtében megjelenő egységesítés, valamint az egyéni vagy lokális igényeket is. A globális piacokon új összefüggésben jelenik meg a termékek és technológiák életciklusa. Megjelenik a „minőségvándorlás” fogalma. A társadalmi kérdések, így a társadalmi felelősségvállalás, a demográfiai tényezók (öregedôn népesség), az egészségügy, a környezeti tényezók és a fenntartható fejlódés kapcsolata a

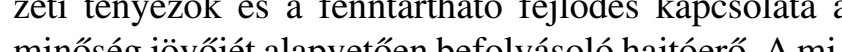
nósé mécelesen jelenik meg az ina is hangsúlyosakká válnak. A XXI. századi technológiák és a minőségmenedzsment-rendszerek kölcsönös hatásaival számolnunk kell, de befolyásuk még nem ítélhetố meg (Molnár, 2009)

\section{TQM - Total Quality Management}

A TQM olyan vezetési filozófia és vállalati gyakorlat, amely a szervezet céljainak érdekében a leghatékonyabb módon használja fel a szervezet rendelkezésére álló emberi és anyagi eróforrásokat. Az Amerika Egyesült Államokban az 1980-as évek közénén fogalfogalazon Topán re és szenieletre alapozva. A TQM felúlról, vezetói szintró kiindulva építkezik. Attogja az egész szervezet muzeset, hemesak a folyamatokra tejed ki, hanem a vezetésre és az erőforrásokra is. A hangsúlyt a vevói elégedettségre és a szervezeti múködés folyamatos fejlesztésére helyezi.

A TQM valamely szervezet azon képességeinek kialakítása és alkalmazása, amelyek révén lehetővé válik az érintettek (vevő́k, tulajdonosok, dolgozók, társadalom, stakeholderek) folyamatosan változó igényeinek kielégítése, és ezáltal a szervezet folyamatos piaci pozíciójának megtartása, illetve erôsítése.

Az amerikai felfogás szerint a TQM egyének, csoportok, szervezetek olyan folyamatos tevékenysége, hogy a „megfelelő dolgokat” az elsố lehetséges alkalommal elvégezzék. Továbbá a TQM az a törekvés is, hogy a kliensek megelégedésére szolgáljanak azáltal is, hogy a kulcsfontosságú folyamatokat rendszeresen mérik és javítják.

A TQM vezetési filozófia és vállalati gyakorlat sikere a felsô vezetésnek a szervezeti teljesítmény folyamatos és teljes körü javítására vonatkozó elkötelezettségén, valamint a célok elérése érdekében választott vezetési eszközökön múlik. A változtatásokhoz szükséges har- madik pillért az azokat ténylegesen végrehajtó, jól képzett, elkötelezett és felhatalmazott teamek jelentik.

Egy másik megközelítés alapján a TQM három alappillére:

a vevốközpontú, még inkább érdekeltközpontú múködés kialakítása és fenntartása,

- a folyamatok tényeken alapuló, szisztematikus és

folyamatos fejlesztése, valamin

- a vevő́központú fejlesztések megvalósítására felhatalmazott, bevont munkatársak.

A minőség guruinak különbözố tanításait a gyakorlati tapasztalattal ötvözve kifejlődött egy egyszerú, de hatékony modell a TQM alkalmazására. Ez a modell a TQM három alapvetố elvére, valamint hat kiegészító elemre épül (Tenner - DeToro, 2005) (1. ábra).

TQM vezetési filozófia alapelvei és kiegészító elemei



Hat Szigma (Six Sigma)

A minőségügyi rendszerek fejlődésének történetében a Hat Szigma gondolkodásmód nem egy forradalmian új jelenség. A minőségszabályozás korszaka egyértelmûen magával hozta a matematikai statisztika elemein megjelenését, az ún szigmában való gondolkodást". A termeló terïleteken a ,hagyományos", 3 s sadást".

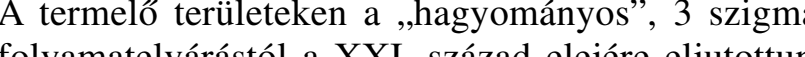
folyamatelván a szinte tökeletes, 6 szigmás elvárásig. A Hat Szigma rendszere nem a 3,4 ppm-es elvárásával hozott újat, hanem azzal, hogy a megfelelố szervezeti értékrend kialakításával és a módszerek szisztematikus alkalmaz sával ez a követelmény teljesíthető. Már nem egy olyan vállalat van a piacon, amely ezt teljesítette, elhárítva ezzel a kételkedốk kifogásait. Az állandó fejlesztések és folyamatjavítások célja, hogy a vevői elvárásoknak megfelelően költséghatékony termelést biztosítson. A Hat Szigma mind méréstechnikailag, mind számí- tástechnikailag „felfegyverzett” folyamatjavítási eljáásokat eredményezett.

„A Hat Szigma valójában kulturális kérdés - a viselkedés egy formája" - azaz a vállalati kultúra megváltoztatása elengedhetetlen a jó minőségú termékek elóállításához és a kapcsolódó szolgáltatások minőségének javításához (Pende et al., 2000).

A Hat Szigma rendszere nem egy készen kapott elóirás, amelyet alkalmazva garantált a siker. Jellegét tekintve sokkal inkább közel áll a Total Quality Management (TQM) gondolatához, mint a minőségszabályozás technikájához. Ez nem jelenti azt, hogy iźrija mind a TQM-et, mind a hagyományos minö (a) (a)

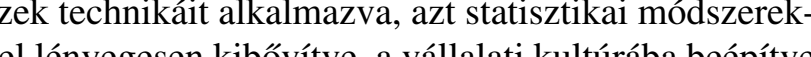
ábra lehet igazán jelentőss eredményeket elérn.

A különbözó területekról számtalan Hat Szigma definíciót kapunk. Gyakran találkozhatunk azzal a megközelítéssel - fóként az üzleti média felól - , hogy a Hat Szigma magas szintû́ technika”, amit fóként mérnökök ", amit fokén használ és statisztikusok mátsák javítsák hogy finoket, eljárálsák termékeiket, eljarásaikat. Ez részben igaz is. A mérések és a statisztika valoban kulcseleme a fejlesztésnek, de ez nem jelenti azt, hogy ennyi lenne az egész. Más megközelítés szerint a Hat Szigma egy közel tökéletes állapotot céloz meg, amely már megfelel a vevő́k elvárásainak. A statisztikai hátterét figyelembe véve ez valóban így van. Hiszen egymillió termékre vagy - szolgáltatásokat tekintve - egymillió lehetőségre kevesebb mint 4 db hibás termék elón cél amelyról tényleg kevés véllala jalóban egy olyan elérte. E megközelítésbő́l következik a Hat Szigm egyik defícíja, amely elsősorban món szigna egyik definíciója, amely elsősorban módszertani olalról közelít:

A Hat Szigma egy szigorú szisztematikus módszer, amely tényalapú menedzsmentmódszereket és statisztikai elemzést használ fel annak érdekében, hogy mérje es javítsa a vállalat múködési teljesítményét, gyakorlatát és rendszerét azáltal, hogy azonosítja és megelózi a gyártási és szolgáltatási folyamatok hibáit, továbba hogy megfeleljen minden érintett elvárásának, vala- 
mint felülmúlja azt a hatékonyság növelésével (www. isixsigma.com)

Mások szerint a Hat Szigma egy kulturális változás, amely befolyásolja a vállalat helyzetét, magasabb vásárlói elégedettséget, jövedelemtermeló képességet és jobb versenyhelyzetet teremtve. Ha megnézzük a Hat Szigmát sikeresen alkalmazó vállalatokat (pl. a General Electricet vagy a Motorolát), akkor láthatjuk, hogy valóban megváltoztatták a vállalati kultúrát.

Ugyanakkor anélkül is lehetséges a Hat Szigma be vezetése hogy szembemennénk a vállalat jelenlegi kutúrájával. Lehet, hogy csak inkább finomítani kell azt.

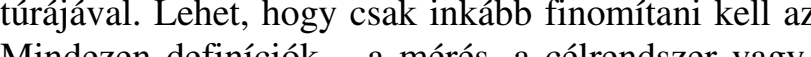
Mindezen definiciok - a mées, a celrendszer vagy a kulturális vallozás - csak feladatait és lehetóségeit. Osszegezve tehát a következ
definíciót adhatjuk meg (Pende et al., 2000):

A Hat Szigma egy széles körú és rugalmas rendszer az üzleti siker elérése, fenntartása és maximalizálása érdekében. A Hat Szigmát a vevói elvárások pontos megértése, a tények, adatok és statisztikai elemzések módszeres alkalmazása és a menedzselésre, fejlesztés és az ïzleti folyamatok ujratervezésére forditott kiiloés az üzleti

A Hat Szigma alkalmazásával elérhetó üzleti siker megfogalmazása elég tág fogalom. Eddig a Ha Szigma különféle eredményeket bizonyított, néhány ezek közül:

- költségcsökkenés

- termelékenységnövekedés,

- piaci részesedés növekedése

- ügyfelek megtartása,

- ciklusidố csökkenése

- selejtarány csökkenése

- vállalati kultúra megváltozása

- termék- vagy szolgáltatásjavulás.

\section{Lean management}

A lean angol szó, eredeti jelentése: karcsú, rugalmas, könnyed.

A lean gyártási szemlélet gyökerei a Toyota Motor Companyhoz vezethetók vissza, ahol a gyártási struktúrát az ötvenes évek elejétốl kezdték megreformáln Célul túzték ki, hogy pár éven belül utolérik, sốt maguk mögé utasítják az amerikai autópiacot, átvéve az iparág vezetô szerepét.

Ennek elengedhetetlen feltétele volt a veszteségek felismerése, pontos beazonosítása, vizualizálása és eliminálása. Tapasztalataikat megosztva a világgal terjed el filozófiájuk, mely ma már minden világszínvonalú cég életében elengedhetetlen eleme a mindennapok- nak. A piacon maradás feltétele, hogy alkalmazkodjunk a nap mint nap változó igényekhez.

Elemei, eszköztára igen gazdag, a teljesség igénye nélkül: pl. TPM, 5S, vállalati filozófia, FMEA, PDCA, benchmarking, OEE, vizualizálás, KAIZEN stb. Ezen eszközök együttes, komplex alkalmazása olyan lehetóséget ad a cégek kezébe, amelyekkel a hibák észrevehetoók, megelőzhetốk és logikus, veszteségek nélkül múködô folyamatok üzemeltethetók.

Taiichi Ohno a termelési folyamatokban hét veszteségforrást határozott meg: túltermelés, készletek, váraozás, felesleges múveletek, felesleges mozgat́s, feles-

A lean eszkózei, módszerei nagyon egyszerúek, konnyen belâtható eredményeket hozhatnak. Lényegében nem képviselnek mást, mint a ,józan ész” logikáját. Enck ellené alkalmazásuk általában nehézségekbe ütközik, lassú folyamat hoz átfogó eredményeket. Mi ennek az oka? Egyrészt a lean szemléletének bevezetése egyben kultúraváltást, paradigmaváltást is jelent. A szervezet minden dolgozója fejében meg kell, hogy szülessen az új szemlélet, és annak felismerése, hogy mi a lean management alkalmazásának a célja, másrészt ellentétes a sok szervezetben gyökeret eresztett projektszemlélettel.

A lean egy szemlélet, gondolkodásmód, amelyet elkezdeni lehet, de fenntartani a hosszú távú célok kijelölésével kell. Harmadrészt a lean szemlélet az európai löesevel kell. Ha fence

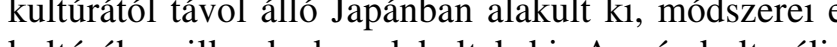
kultura beágyazottsággal rendelkezó országokban sikeresen csak erős vezető́i elkötelezettség mellett, megfelelố emberierơforrás-eszközök támogatásával alkalmazható (Kotter, 2007).

A lean management három alapelve:

- költségcsökkentés a vállalati folyamatokban felmerülô veszteségek kiküszöbölésével,

folyamatos fejlesztés

- az alkalmazottak bevonás

A hatékonyság és a minôség tudatos, állandó javítása a fenntartható versenyképesség kulcstényezőjévé vált. A világszerte elterjedt, vezetố multinacionális vállalatok és beszállítóik által egyre nagyobb számban kkalmazott Lean Management rendszer elmélete és gyakorlata is ezt a célt szolgálja: a lean filozófia alkalmazásával - folyamatos fejlesztés útján - szisztematikus módszertan segítségével azonosíthatóak és kiküszöbölhetőek a veszteségek, a termelés vagy szolgáltatás folyamata a vásárlói igények alapján optimalizálható. A módszertan ötvözi a hatékonyság- és minőségfejlesztés nemzetközileg elismert gyakorlatait, célja a hatékonyság folyamatos növelése a vállalat valamenny érintett dolgozójának bevonásával. Ennek érdekében az esetleges és elkülönüló pozitív kezdeményezéseket tervszerú, rendszerbe épített folyamatos fejlesztéssel váltja fel.

A lean szervezetek versenyképessége folyamatosan javul, a piac igényeihez rugalmasan alkalmazkodnak, gyorsabban és pontosabban szállítják termékeiket vagy szolgáltatásaikat, és a költségszintjüket alacsonyabban tudják tartani, mint versenytársaik. Bár a leon menedzsment alapelvei minden vállalatnál azonosak, sikerhez.

szervezet iránti bizalom, csökkennek a költségek, nöekszik a munkatársak elkötelezettsége, mivel ốk is észesednek a Lean Hat Szigma alkalmazásának eredményeiből (Aschner, 2007).

\section{Összefoglalás}

Vizsgáljuk meg, hogy az elózókben ismertetett rendszerekben melyek a közös elemek! Ehhez a teljesség igénye nélkül a TQM, a Hat Szigma és a lean különbözô jellemzőit vesszïk számba.

Az 1. táblázat információiból is látható, hogy a termelố- és szolgáltatószervezetekben alkalmazott minő-

1. táblázat

A TQM, Hat Szigma és lean jellemzőinek összehasonlítás

\begin{tabular}{|c|c|c|c|}
\hline Jellemzó & TQM & Hat Szigma & Lean \\
\hline Vezetói elkötelezettség & alapvetót & alapvetót & szükséges \\
\hline Szervezeti kultúra változtatása & alapvetó & alapvetó & alapvetót \\
\hline Vevói fókusz & alapvetó & alapvetó & alapvetót \\
\hline Üzleti siker & alapvetót & alapvetó & alapvetố \\
\hline Különböző menedzsmentdiszciplínák alkalmazása & alapvetót & szükséges & alapvetố \\
\hline Folyamatmenedzsment & alapvetót & alapvetót & szükséges \\
\hline Munkatársak oktatása & alapvetót & alapvetót & alapvetó́ \\
\hline Dolgozók bevonása & alapvetó & szükséges & szükséges \\
\hline Keresztfunkcionális teamek & szükséges & szükséges & szükséges \\
\hline Munkatársak felhatalmazása & alapvetó & szükséges & alapvetó \\
\hline Matematikai statisztikai szemlélet & szükséges & alapvetót & szükséges \\
\hline Hatékonysági mutató́k (költség, termelékenység, selejt arány...) & szükséges & szükséges & alapvetố \\
\hline Az adott területre jellemzó módszerek szisztematikus, komplex alkalmazása & alapvetó & alapvetó & alapvetố \\
\hline Veszteségforrások csökkentése & szükséges & szükséges & alapvetố \\
\hline Projektek & szükséges & alapvetó & nem jellemzó \\
\hline
\end{tabular}

Lean Hat Szigma

A lean és a Hat Szigma az utóbbi években gyakran emlegetett fogalmak. Alkalmazásával a két fontos fejlesztési irányzat kiegészíti egymást: a sikeres üzleti folyamatok megvalósítását a két szemlélet együttes alkalmazása támogatja. A feladatok jobb és olcsóbb elvégzését biztosítja a Hat Szigma, a hatékonyabb elvégzését pedig a lean elvek alkalmazása.

A Lean Hat Szigma az alapokból következóen hat sos vezetési eszköz a szervezet stratégiájának megvalósításához, illetve taktikai ezzköz a nyereségek és veszteségek elemzésével foglalkozó menedzserek számár A módszer alkalmazásának eredményeként a vevók partnerek igényeiknek megfelelő (jobb) termékeket, szolgáltatásokat kapnak, amelynek révén növekszik ségorientált vezetési rendszerek (TQM, Hat Szigma, ean) azonos alapokon múködőrendszernek tekinthetők. rendszerek alapjának a Total Quality Management vezetési filozófiát tekinthetjük. Természetesen a közös lapok mellett a rendszerek sajátos elemei speciális fótenek a különböző vezetési rendszerek alkalmazásakor

Egy adott rendszerfilozófia alkalmazása csak abban az esetben jelent sikereket eredményező múködést a szervezeteknél, ha az alapelvek szervezetre történó „testre szabása” megtörténik a szervezet múködés módja és szervezeti kultúrájának figyelembevételével. Mindhárom rendszert jellemzi (mint ahogy áltaában a minőségmenedzsment-rendszereket), hogy először a termelôszektorokban vezették be óket, majd napjainkban a nem termelố szektorokban múködô 
szervezetek esetében is sikeres alkalmazásokra kerül sor. Itt fokozottan oda kell figyelni a szektorspecifikus múködésre.

Az áttekintett vezetési rendszerek mindegyike a különbözô menedzsmentdiszciplínák szinergikus alkalmazását igényli.

Mindhárom menedzsmentfilozófia alkalmazását széles eszköztár támogatja, amelyek erôteljesen támaszkodnak a hagyományos minőségmenedzsment módszereire. Jelentôs mértékben alkalmaznak azonos eszközöket, módszereket, de az egyes vezetési rendszerekben megjelennek az adott rendszer specifikus eszközei is.

A vizsgált minőségorientált menedzsmentrendszerek hatékony múködése a különböző módszerek szisztematikus alkalmazását igényli, de a módszerek tömeges alkalmazása önmagában nem tekinthetô az adott vezetési rendszernek.

\section{Felhasznált irodalom}

Anttila J. (2008): A minőségmenedzsmenttől a menedzsment minóségéig. Minóség és Megbízhatóság 2008/1., 14-26. o.

Aschner G. (2007): A Lean Hat Szigma Magyar Minőség, 2007/6, 2-8. o.

Kotter E. (2007): A lean útján haladva. Magyar Minőség, 2007/10, 2-11. o.

Molnár P. (2009): A minőség jövóképét meghatározó fontosabb tényezók. Minőség és Megbízhatóság 2009/1., 4-12. 0 .

Pande, P.S. - Neuman R.P. - Cavanagh R.R. (2000): The Six Sigma way: how GE, Motorola, and other top companies are honing their performance; McGraw Hill Companies, Inc., New York

Parányi Gy.(2006): Merre halad a minóség ügye? Magyar Minôség, 2006/2, 8-13. o.

Rózsa A. (2009): Lean, Hat Szigma, avagy mi lesz veled TQM? Magyar Minőség, 2009/1., 45-50. o

Tenner, A.R. - I.J. DeToro (2005): Teljes körú Minôségmenedzsment TQM, Múszaki Könyvkiadó, Budapest.

Varga L. (2008): Minőségmenedzsment vagy a menedzsment minősége? Minőség és Megbízhatóság 2008/1., 4-13. o. 